\title{
KERASIONALAN PENGGUNAAN OBAT ISPA PADA ANAK DI INSTALASI RAWAT JALAN RSU KOTA TANGERANG SELATAN TAHUN 2016
}

\author{
Humaira Fadhilah, Fitri Azani Ahmad, M.Hasan \\ Sekolah Tinggi Ilmu Kesehatan Kharisma Persada \\ Tangerang Selatan, 15417 \\ E-mail: humaira.fadhilah1@gmail.com
}

\begin{abstract}
ABSTRAK
Penggunaan obat di pusat pelayanan kesehatan terutama pada pasien anak yang terdiagnosis ISPA perlu mendapatkan perhatian agar tidak terjadi ketidakrasionalan penggunaan obat. Banyak pengobatan yang diterima anak tidak sesuai dengan kondisi anak tersebut, sehingga hal ini dapat mengakibatkan penggunaan obat yang tidak rasional. Penelitian ini bertujuan untuk mengetahui gambaran rasionalitas penggunaan obatobat ISPA di Rumah Sakit Umum Tangerang Selatan khususnya pada Poli Anak. Penelitian ini menggunakan metode deskriptif dengan pendekatan retrospekif, dalam penelitian ini sebanyak 69 resep pasien anak. Hasil penelitian ini menunjukkan bahwa rasionalitas penggunaan Obat-obat ISPA di RSU Kota Tangerang Selatan pada Januari sampai Desember 2016 pada masing-masing kriteria yaitu Tepat Diagnosa 100\%, Tepat Indikasi Penyakit 100\%, Tepat Pemilihan Obat 100\%, Tepat Dosis 96,5\%, dan Tepat Cara Pemberian obat 99,4\%. Berdasarkan Dosis, dikatakan tidak tepat dosis karena pemberian dosis tidak disesuaikan dengan umur, dan berat badan anak, seperti cetirizine sirup untuk anak 4 tahun menggunakan dosis $1 \mathrm{x}$ sehari $1 / 2$ sendok teh tetapi cetrizine sirup yang tertera pada resep tertulis penggunaan sirup $1 \mathrm{x}$ sehari $3 / 4$ sendok teh hal ini menandakan bahwa dosis yang diberikan kurang dari dosis yang dianjurkan. Tepat Cara Pemberian diperoleh hasil 99,4\%, hasil tidak diperoleh $100 \%$. Dikatakan tidak tepat cara pemberian obat karena obat yang diberikan tidak sesuai dengan cara pemberiannya, seperti dalam resep tertulis obat iliadin (Oxymetazoline) nasal spray yang seharusnya pemberian ditulis seperti di berikan dengan cara disemprotkan ke hidung 2 sampai 3 kali sehari. Berdasarkan hasil penelitian yang telah dilakukan terhadap 69 pasien ISPA yang dirawat jalan di RSU Kota Tangerang Selatan selama periode Januari-Desember 2016 dapat disimpulkan bahwa kerasionalan penggunaan obat ISPA dapat dilihat berdasarkan kriteria tepat dosis sebanyak 96,5\%, tepat cara pemberian obat sebanyak $99,4 \%$, tepat indikasi cara pemilihan obat sebanyak $100 \%$, tepat diagnosis sebanyak $100 \%$ dan tepat cara pemilihan obat sebanyak $100 \%$.
\end{abstract}

Kata Kunci: rasionalitas, obat ISPA, kondisi psikologis

\section{ABSTRACT}

The use of drugs in health care centers, especially in pediatric patients diagnosed with ARI need to get attention in order to avoid drug irrationality. Many of the medications that the child receives do not fit the child's condition, so this may lead to irrational drug use. This study aims to find out the rationality of the use of ARD drugs at Tangerang Selatan General Hospital, especially in Pediatric Poly. This research uses descriptive method with retrospective approach, in this research as many as 69 recipes of pediatric patients. The results of this study indicate that the rationality of the use of ARD Drugs at RSU Tangerang Selatan City in January to December 2016 on each criteria that is 100\% Diagnose Diagnose, Precise Indication of 100\% Disease, Picking 100\%, Right Dose 96.5\%, and Appropriate Method of Medication 99.4\%. Based on the dosage, it is said that the dosage is not appropriate because the dose is not adjusted for age, and the child's weight, such as cetirizine syrup for 4-year-old children using a dose of $1 x$ daily $1 / 2$ teaspoon but cetrizine syrup listed on the prescription written use of syrup $1 x$ daily $3 / 4$ spoon tea this indicates that the dose given is less than the recommended dose. The Right Way of Giving obtained $99.4 \%$ results, the results are not obtained $100 \%$. It is said that the drug is not appropriate because the drug given is not appropriate with the way it is given, as in the written recipe of iliadine drug (Oxymetazoline) nasal spray which should be written as given by sprayed to the nose 2 to 3 times a day. Based on the result of research that has been done to 69 patients of street-treated ARI in South Tangerang City General Hospital during January-December 2016 period, it can be concluded that the rationale of ISPA drug use can be seen based on $96.5 \%$ exact dosage criteria, 4\%, the exact indication of how the selection of drugs as much as 100\%, 100\% accurate diagnosis and the right way of drug selection as much as $100 \%$.

Keywords: rationality, ARD drug, psychological condition 


\section{LATAR BELAKANG}

Menurut WHO (2003) Penyakit Infeksi Saluran Pernafasan Akut (ISPA) sendiri merupakan salah satu penyakit penyebab kematian anak di seluruh dunia. salah satu contoh pada penyakit infeksi penggunaan antibiotik mempunyai peranan penting dalam proses penyembuhan. Penggunaan antibiotik hendaknya digunakan secara rasional karena mempunyai dampak yang besar salah satunya yaitu terjadinya resisten terhadap antibiotik bila digunakan secara tidak rasional.

Keputusan Menteri Kesehatan Republik Indonesia tahun 2002 menyebutkan bahwa penyakit Infeksi Saluran Pernafasan Akut (ISPA) di Indonesia selalu menempati urutan pertama penyebab kematian yang sering terjadi pada anak. Selain itu ISPA juga sering berada pada daftar 10 penyakit terbanyak di Rumah Sakit yang ada di Indonesia (Depkes, 2000).

Penelitian yang dilakukan oleh Erna Fatmawati (2010) berjudul "Rasionalitas Penggunaan Obat Infeksi Saluran Pernafasan Akut di Puskesmas Kecamatan Banyudoyono dan Kecamatan Teras Kabupaten Boyolali” menunjukkan adanya kasus irasional dalam penggunaan obat ISPA pada pasien anak. Oleh sebab itu, penggunaan obat di pusat pelayanan kesehatan terutama pada pasien anak yang terdiagnosis ISPA perlu mendapatkan perhatian agar tidak terjadi ketidakrasionalan penggunaan obat. Banyak pengobatan yang diterima anak tidak sesuai dengan kondisi anak tersebut, sehingga hal ini dapat mengakibatkan penggunaan obat yang tidak rasional. Menurut WHO (2002) pengobatan yang ideal untuk anak adalah sesuai dengan umur, kondisi psikologis dan berat badan anak.

Berdasarkan uraian di atas, penggunaan obat ISPA perlu mendapatkan perhatian khusus, mengingat angka kejadian penyakit ISPA di RSU Kota Tangerang Selatan cukup tinggi, Oleh karena itu, peneliti tertarik untuk melakukan penelitian tentang "Kerasionalan Penggunaan Obat ISPA Pada Anak di Instalasi Rawat Jalan RSU Kota Tangerang Selatan Periode Tahun 2016". 


\section{METODE}

Penelitian ini merupakan penelitian analisis deskriptif dengan pengambilan data secara retrospektif yang didasarkan pada catatan medik. Populasi penelitian ialah semua data rekam medis dan resep pasien ISPA pada anak yang menggunakan obat-obatan ISPA yang menjalani rawat jalan di RSU Kota Tangerang Selatan bulan januaridesember 2016. Penelitian dilakukan di Instalasi Rawat Jalan dan Rekam Medik Rumah Sakit Umum (RSU) Kota Tangerang Selatan pada bulan Mei 2017. Sampel dari penelitian ini adalah resep yang mengandung obat ISPA terpilih dari populasi yang memenuhi kriteria

\section{HASIL}

\section{a. Data Karakteristik Berdasarkan}

\section{Usia dan Jenis Kelamin}

Data yang menunjukkan karakteristik pasien rawat jalan pada poli Anak di RSU Kota Tangerang Selatan selama periode Januari- penelitian. Teknik pengambilan sampel yang digunakan dalam penelitian ini adalah teknik kuota sampling yang memenuhi kriteria inklusi.

Kriteria kerasionalan yang dilihat pada penelitian ini ialah tepat dosis, tepat cara pemberian obat, tepat indikasi, tepat diagnosis, dan tepat cara pemilihan obat. Pengumpulan data dimulai dengan mengumpulkan resep yang mengandung obat ISPA yang telah dilayani dari Bulan Januari sampai Desember 2016, kemudian resep dicocokkan dengan data rekam mediknya. Setelah data diperoleh, data dibuat dalam bentuk tabel kemudian dianalisa.

Tabel 1. Karakteristik Pasien ISPA Rawat Jalan Poli Anak di RSU Kota Tangerang Selatan Periode Januari-Desember 2016 ( $N=69)$

\begin{tabular}{llll}
\hline Karakteristik & Kategori & N & \% \\
\hline Usia & 0-5 tahun & 35 & 50,27 \\
& 6-11 tahun & 24 & 34,79 \\
& 12-24 tahun & 10 & 14,49 \\
\hline Jenis Kelamin & Laki-laki & 35 & 50,72 \\
& Perempuan & 34 & 49,28
\end{tabular}


Berdasarkan kelompok usia yang menderita ISPA di Instalasi rawat jalan di RSU Kota Tangerang Selatan selama periode Januari-Desember 2016, diperoleh kelompok usia 0-5 tahun sebanyak 35 pasien(50,72\%), kelompok umur 6-11 tahun sebanyak 24 pasien $(34,79 \%)$ dan kelompok umur 12-14 tahun sebanyak 10 pasien $(14,49 \%)$.

\section{b. Diagnosis}

Data yang menunjukkan karakteristik pasien rawat jalan pada poli Anak di RSU Kota Tangerang Selatan selama periode
Berdasarkan kelompok jenis kelamin yang menderita ISPA di Instalasi rawat jalan di RSU Kota Tangerang Selatan selama periode Januari-Desember 2016, diperoleh kelompok jenis kelamin laki-laki sebanyak 35 pasien $(50,72 \%)$ dan kelompok jenis perempuan sebanyak 34

pasien $(49,28 \%)$.

Tabel 2. Karakteristik Pasien ISPA Rawat Jalan Poli Anak di RSU Kota Tangerang Selatan Periode Januari-Desember 2016 Berdasar Diagnosa.

\begin{tabular}{clcl}
\hline No & \multicolumn{1}{c}{ Diagnosa } & $\mathbf{N}$ & \% \\
\hline 1. & Bronkhitis & 29 & 42,02 \\
\hline 2. & Rhinobronkhitis & 17 & 24,64 \\
\hline 3. & ISPA & 9 & 13,04 \\
\hline 4. & Rhinofaringitis & 9 & 13,04 \\
\hline 5. & Rhinitis Alergi & 2 & 2,90 \\
\hline 6. & Bronkiolitis & 1 & 4,35 \\
\hline 7. & Faringitis & 1 & 4,35 \\
\hline 8. & Tonsilofaringitis & 1 & 1,45 \\
\hline & Jumlah & $\mathbf{6 9}$ & $\mathbf{1 0 0}$
\end{tabular}

Berdasarkan kelompok diagnosa yang menderita ISPA di Instalasi rawat jalan di RSU Kota Tangerang Selatan selama periode
Januari-Desember 2016 yang menerima obat ISPA berdasar diagnosa dapat dilihat pada tabel 2 . 
tonsilofaringitis dengan jumlah

$(1,45 \%)$

terendah yaitu sebanyak 1 pasien

\section{c. Evaluasi Kerasionalan}

Evaluasi kerasionalan

yang menderita ISPA yang dirawat inap di RSU Kota penggunaan obat ISPA dilakukan terhadap data rekam medik pasien Tangerang selama periode Januari-Desember 2016.

Tabel 3. Rasionalitas Penggunaan Obat - obat ISPA pada Resep Pasien Rawat Jalan RSU Kota Tangerang Selatan sesuai dengan Kriteria (POR)

\begin{tabular}{|c|c|c|c|c|c|c|}
\hline \multirow[b]{2}{*}{ No } & \multirow[b]{2}{*}{ Kriteria POR } & \multicolumn{2}{|c|}{ Rasional } & \multicolumn{2}{|c|}{ Tidak Rasional } & \multirow[b]{2}{*}{$\begin{array}{c}\text { Jumlah } \\
\text { Obat }\end{array}$} \\
\hline & & $\mathbf{N}$ & $\%$ & $\mathbf{N}$ & $\%$ & \\
\hline 1 & Tepat Dosis & 170 & 96,6 & 6 & 3,4 & 176 \\
\hline 2 & Tepat Cara Pemberian & 175 & 99,4 & 1 & 1,5 & 176 \\
\hline 3 & Tepat Indikasi & 176 & 100 & 0 & 0 & 176 \\
\hline 4 & Tepat diagnosa & 170 & 100 & 0 & 0 & 176 \\
\hline 5 & Tepat Cara Pemilihan Obat & 175 & 100 & 0 & 0 & 176 \\
\hline
\end{tabular}

Sumber: Data Primer

$\mathrm{E}$

valuasi kerasionalan dilakukan

meliputi beberapa kriteria kerasionalan yaitu tepat dosis, tepat cara pemberian obat, tepat indikasi penyakit, tepat diagnosis dan tepat cara pemilihan obat. Berdasarkan tepat indikasi diagnose, dan cara pemilihan obat, seluruhnya sudah rasional $100 \%$.

\section{DISKUSI}

Berdasarkan diagnosa yang tertera pada status pasien anak dari Rekam Medis dari 69 resep didapat diagnosa penyakit yaitu Infeksi Saluran Pernafasan Akut (ISPA) yang terdiri dari infeksi saluran pernafasan atas dan infeksi saluran pernafasan bawah. Infeksi
Saluran Bagian Atas seperti

Tonsilofaringitis $(1,45 \%)$, Rhinofaringitis (13,04\%), Rhinitis Alergi (2,90\%), Rhinofaringitis $(13,04 \%)$, Faringitis $(1,45 \%)$, dan Infeksi Saluran Pernafasan Bagian Bawah seperti Bronkhiolitis 
(4,35\%), Bronkhitis $(42,02 \%)$, dan

Rhinobronkhitis $(24,64 \%)$.

Diagnosa penyakit

berdasarkan resep pasien rawat jalan khususnya pada Poli Anak di RSU Kota Tangerang Selatan, dengan diagnosa penyakit Infeksi Saluran Pernafasan Akut (ISPA) berdasarkan usia tertinggi yaitu 1 bulan sampai 5 Tahun sebanyak 35 Resep dengan persentase $50,72 \%$. Hal ini diperkuat bahwa kriteria usia penyandang ISPA di Indonesia adalah balita 1 tahun sampai 4 tahun yaitu sebesar 1020\% (Depkes RI, 2001). Dikarenakan anak berumur 1 bulan sampai 5 tahun sangat rentan terkena penyakit ISPA yang dapat disebabkan oleh faktor lingkungan yang kotor dan daya tahan tubuh mereka belum terlalu kuat.

Berdasarkan Jenis Kelamin Pasien Anak dengan ISPA di Instalasi Rawat Jalan RSU Kota Tangerang Selatan, jumlah pasien ISPA dengan jenis kelamin lakilaki lebih banyak dibandingkan dengan jumlah pasien ISPA jenis kelamin Perempuan. Jumlah pasien perempuan yaitu sebanyak $50,72 \%$ sedangkan laki-laki 49,28\%. Dari hasil data diatas dapat disimpulkan bahwa penyakit ISPA dapat mengenai balita lakilaki maupun perempuan namun persentase laki-laki sedikit lebih besar dibandingkan dengan anak perempuan. Hasil penelitian jenis kelamin tidak ada hubungan yang bermakna antara jenis kelamin dengan kejadian ISPA pada anak (Nur, 2010).

Jumlah pasien bronkhitis lebih banyak dibandingkan dengan jenis penyakit ISPA yang lainnya yaitu mencapai $42,02 \%$. Penyakit bronkhitis lebih sering diderita oleh pasien anak, penyebab bronkhitis pada anak biasanya adalah virus, bakteri, alergi, polusi, asep debu dan iritasi asap rokok (Maryunani, 2010).

Penilaian tentang kesesuaian penggunaan obatobatan ISPA pada anak di RSU Kota Tangerang selatan pada pasien umum Rawat jalan di Poli Anak dengan kriteria Penggunaan Obat Rasional (POR) yang meliputi Tepat Diagnosa, Tepat Indikasi Penyakit, Tepat Pemilihan Obat, Tepat Dosis, dan Tepat Cara Pemberian Obat.

Dari lima kriteria POR diatas ada dua kriteria yang hasilnya tidak $100 \%$ rasional, 
yaitu kriteria obat tepat dosis dan tepat cara pemberian obat. Hal ini dikarenakan adanya pemberian dosis tidak disesuaikan dengan usia, berat badan anak.

Tepat Dosis diperoleh 96,6\%, hasil tidak diperoleh 100\%. Berdasarkan Dosis, dikatakan tidak tepat dosis karena pemberian dosis tidak disesuaikan dengan umur, dan berat badan anak , seperti cetirizine sirup untuk anak 4 tahun menggunakan dosis $1 \mathrm{x}$ sehari $1 / 2$ sendok teh tetapi cetrizine sirup yang tertera pada resep tertulis penggunaan

\section{SIMPULAN}

Berdasarkan hasil penelitian yang telah dilakukan terhadap 69 pasien ISPA yang dirawat jalan di RSU Kota Tangerang Selatan selama periode Januari-Desember 2016 dapat disimpulkan bahwa kerasionalan penggunaan obat ISPA dapat

\section{DAFTAR PUSTAKA}

Departemen Kesehatan RI. 2000. Pedoman pemberantasan penyakit Infeksi saluran pernafasan akut. Jakarta: Dirjen PPM. sirup 1 x sehari $3 / 4$ sendok teh hal ini menandakan bahwa dosis yang diberikan kurang dari dosis yang dianjurkan (Dipiro, 2009).

Tepat Cara Pemberian diperoleh hasil $99,4 \%$, hasil tidak diperoleh 100\%. Dikatakan tidak tepat cara pemberian obat karena obat yang diberikan tidak sesuai dengan cara pemberiannya, seperti dalam resep tertulis obat iliadin (Oxymetazoline) nasal spray yang seharusnya pemberian ditulis seperti di berikan dengan cara disemprotkan ke hidung 2 sampai 3 kali sehari.

dilihat berdasarkan kriteria tepat dosis sebanyak $96,5 \%$, tepat cara pemberian obat sebanyak 99,4\%, tepat indikasi cara pemilihan obat sebanyak $100 \%$, tepat diagnosis sebanyak $100 \%$ dan tepat cara pemilihan obat sebanyak $100 \%$.

Dipiro, J., et al. 2009. Pharmacoterapy Handbook 7th ed. America: MC GrawHill Companies, Inc. 
Direktorat Jendral. 2012. Pengendalian penyakit dan penyerahan lingkungan. Pedoman pengendalian infeksi saluran pernafasan akut. Jakarta: Kemenkes RI.

Maryunani, Anik. 2010. Ilmu kesehatan anak dalam kebidanan. Jakarta: Trans info media
Nur, H.2010. Faktor - faktor yang berhubungan dengan kejadian ISPA pada balita. Medan: Fakultas Kesehatan Msyarakat. USU.

WHO. 2003 Respiratory acute infections. Dalam Trimutiara. Infeksi saluran pernafasan akut. Makasar; Fakultas UIN. 